\title{
The effect of HAp on Characterization of MgZn-xHAp Biocomposites
}

\author{
Henni Sitompul*, Yohanes E Gunanto, and Maya P. Izaak \\ Department of Physics Education, Pelita Harapan University, Kelapa Dua, Tangerang 15811
}

\begin{abstract}
Magnesium is a metal that is being developed as a biodegradable bone implants. Various studies conducted to produce material that was superior in mechanical properties and corrosion resistance. One of them is making Mg-based composite. This study aims is to see the effect of HAp on MgZnHAp composites. The biocomposites were synthesized by mixing the HAp powder on MgZn powder with composition of 5\%, 7\% and $9 \%$ using ball milling for 30 minutes. The material was sintered at $350^{\circ} \mathrm{C}$ and held for one hour. Biocomposites were characterized by SEM/EDS, X-ray diffraction (XRD) and Potentiostat. The test results showed that the composition of the HAp affected biocomposites characterization. The larger HAp composition resulted smaller grain size, smaller crystallite size, and better in corrosion resistance. The largest corrosion rate was found in the $\mathrm{NaCl}$ test solution and the lowest was in aquadest.
\end{abstract}

Keywords: biocomposite; bone implant; HAp; MgZn; MgZn-xHAp.

*Corresponding author: henni.sitompul@uph.edu

Article history: Received 14 August 2020, Accepted 08 November 2020, Published January 2021. http://dx.doi.org/10.12962/j24604682.v17i1.6988

2460-4682 (c)Departemen Fisika, FSAD-ITS

\section{INTRODUCTION}

The biomaterial is a material except than drug that can be applied and processed directly to body tissues within a certain period of time [1]. There are two types biomaterial properties namely inert biomaterials and biodegradable biomaterials. Biodegradable biomaterials are widely developed in orthopedic field $[2,3]$, this is because the bones will recover after around 4-7 months [4]. Bone implants are only needed during the recovery period after that, the implant must be removed. There are three types of biodegradable materials were developed in orthopedics field, that is magnesium-based biomaterials (Mg), Zinc-based biomaterials (Zn), and Iron-based biomaterials (Fe). Mg-based biomaterials are the most widely developed because it has a young modulus that is closer to the bone [5-7]. In addition, $\mathrm{Mg}$ is one of the important nutritional element and plays an important role in the synthesis of proteins and nucleic acids in the human body [3].

The utilization of $\mathrm{Mg}$ as an implant material has been started in 1808 and is being continued to be developed today [5-10]. The research main focus of Mg-based biomaterials are to improve its mechanical properties and corrosion resistance. The most development is being done by combining $\mathrm{Mg}$ with other metals to form Mg-based alloys [2,5-7] or combine $\mathrm{Mg}$ with other materials to form Mg-based composites [8-11]. $\mathrm{Zn}$ is one of the degradation metals that can be combined with $\mathrm{Mg}$. It is an important element in the human body and involved in various aspects of cellular metabolism in the body. $\mathrm{Mg}$ plays a role in improving the function of enzymes, supports immune function, supports protein and DNA synthesis, and supports wound healing. An in vitro study showed that Zinc also plays a role in the fight against bacterial colo- nization in the DNA [12]. Combines $\mathrm{Zn}$ with $\mathrm{Mg}$ as a $\mathrm{MgZn}$ alloy resulted material with good mechanical properties, have good cytotoxicity, and have the lowest hydrogen evolution rate while be applied as a bones implant [13-15].

HAp is a bioceramic that can dissolve in the human body. Its chemical properties are very similar to the inorganic mineral components in the bone [8]. HAp can integrate well with the environment around the bone, encourage the formation of new bone, bind to the newly formed bone, and repair damaged bone tissue [16]. This makes HAp very potential to be applied in the field of orthopedic. However, hydroxyapatite has weak mechanical properties so it is not good enough to be used as a bone implant. Therefore HAp is usually used as a composite filler for bone implant materials. In this study, HAp will be composited with $\mathrm{MgZn}$ and see the effect on the characteristics of the resulting material. HAp will be added with a different composition so that the effect of HAp can be seen in the material. Thus the aim of this study is to see the effect of HAp on the characteristics of the MgZnHAp biocomposites.

\section{EXPERIMENTAL}

Equipment and materials are used in this study were SEM JED 2300, uniaxial compacting AKS 3030, Potentiostat, Furnace 47900, PANalytical XRD, Ball Milling, Mg Powder, Zn Powder, HAp Powder. There are three categories of biocomposites that were synthesized in this study are (1) MgZn-5\% HAp; (2) MgZn-7\%Hap; and (3) MgZn-9\%HAp. The sample preparation begins by mixing $\mathrm{Mg}$ and $\mathrm{Zn}$ powder with a composition of 94:6 using ball milling. The mixing was carried out for 4 hours in order to obtain a homogeneous mixture. 
TABLE I: Lattice parameter and volume of the $\mathrm{Mg}$ in the $\mathrm{MgZn-xHAp} \mathrm{biocomposite.}$

\begin{tabular}{cccc}
\hline \hline Lattice & MgZn- & MgZn- & MgZn- \\
Parameter & 5\%HAp & 7\%HAp & 9\%HAp \\
\hline & & & \\
a $(\AA)$ & 3.2075 & 3.2071 & 3.2070 \\
$\mathrm{~b}(\AA)$ & 3.2075 & 3.2071 & 3.2070 \\
$\mathrm{c}(\AA)$ & 5.2072 & 5.2075 & 5.2066 \\
$\mathrm{~V}\left(\mathrm{pm}^{3}\right)$ & $46.39545 / 10^{6}$ & $46.38450 / 10^{6}$ & $46.37388 / 10^{6}$ \\
\hline \hline
\end{tabular}

After that, HAp is added and milled for 30 minutes. The mixture was compacted by uniaxial compacting AKS 3030 at a pressure of $570 \mathrm{MPa}$ to obtain pellets with a size of $1.5 \mathrm{~cm}$. The sample was covered with a pirex tube first, then continued with the sintering process. The sintering process was carried out by Furnace 47900 at $350^{\circ} \mathrm{C}$ with 1 hour holding.

\section{RESULTS AND DISCUSSION}

\section{Phase analysis of MgZn-xHAp biocomposite}

The X-ray Diffraction (XRD) test was carried out at a range of 2 from $25-85^{\circ}$. There are three phases identified in these samples, i.e. Mg (ICDD 98-018-1728), Zn (ICDD 98-042-1015) and HAp (ICDD 98-005-6311). X-ray diffraction pattern of MgZn-xHAp biocomposites is shown in Fig. 1(a). There are no significant changes in the XRD pattern of MgZn-xHAp biocomposites compared to the XRD pattern of the sample without HAp. However, if it compared to the XRD pattern of $\mathrm{MgZn}$ before sintering, it can be seen that the intensity of $\mathrm{Mg}$ peaks in biocomposites will be higher and the intensity of $\mathrm{Zn}$ peaks is getting lower. This shows that some $\mathrm{Zn}$ atoms substituted $\mathrm{Mg}$ atoms in the $\mathrm{Mg}$ crystal structure during sintering process. Based on Hume Rothery rules, $\mathrm{Zn}$ can dissolve into $\mathrm{Mg}$ to form a solid solution. $\mathrm{Zn}$ and $\mathrm{Mg}$ have the same crystal structure and the size of the $\mathrm{Zn}$ atomic radius (134 pm) is $11 \%$ smaller than the size of the $\mathrm{Mg}$ atomic radius (160 pm). The $\mathrm{Zn}$ peaks that were still visible in the XRD pattern indicated that not all of the $\mathrm{Zn}$ had dissolved in $\mathrm{Mg}$. There are two possible causes for this could happen. The first is the amount of $\mathrm{Zn}$ that has approached the solubility limit in $\mathrm{Mg}$. $\mathrm{Zn}$ solubility limit in $\mathrm{Mg}$ is $6.2 \%$ at $340^{\circ} \mathrm{C}$ [17], while in this study the amount of $\mathrm{Zn}$ added is $6 \%$. The second cause is the presence of HAp in the sample. This can be seen from the XRD pattern in Figure 1a where the $\mathrm{Zn}$ intensity is greater when the HAp composition increases.

The HAp peaks are not visible in the biocomposites XRD pattern even though it has been added up to $9 \%$. This is due to the position of the highest peak of HAp (31.7730) almost coincided with one of the $\mathrm{Mg}$ peaks $\left(32,194^{\circ}\right)$, while the intensity of the other HAp peaks is not too large. The XRD pattern of HAp is shown by Fig. 1(b). Several HAp peaks will be seen if it is highlighted in a narrower range of 2 (250400) and a lower intensity range (300-1100) as has shown by Fig. 2. The peak intensity will be higher if the percentage of
TABLE II: Lattice parameter and volume of the $\mathrm{Zn}$ in the MgZn-xHAp biocomposite.

\begin{tabular}{cccc}
\hline \hline Lattice & MgZn- & MgZn- & MgZn- \\
Parameter & 5\%HAp & 7\%HAp & 9\%HAp \\
\hline & & & \\
$\mathrm{a}(\AA)$ & 2.670 & 2.666 & 2.670 \\
$\mathrm{~b}(\AA)$ & 2.670 & 2.666 & 2.670 \\
$\mathrm{c}(\AA)$ & 5.002 & 4.978 & 5.002 \\
$\mathrm{~V}\left(\mathrm{pm}^{3}\right)$ & $30.88138 / 10^{6}$ & $30.64120 / 10^{6}$ & $30.88138 / 10^{6}$ \\
\hline \hline
\end{tabular}

HAp is greater. The HAp peaks that appear are in the lattice plane (211) at 31.70 , lattice plane (002) at $25.8^{\circ}$ and lattice plane (112) at $32.2^{\circ}$.

To determine the effect of HAp on the lattice parameters $\mathrm{Mg}$ and $\mathrm{Zn}$, further analysis was carried out using a high score. Table I shows that the addition of HAp cause Mg lattice parameter is smaller, which means that the $\mathrm{Mg}$ crystal size decreases. The lattice parameters of $\mathrm{Zn}$ after adding HAp are shown in Table II. Based on this table, it can be seen that the lattice parameters of the samples added 5\% and 9\% HAP have the same size but the samples added 7\% HAp have smaller lattice parameters.

\section{Microstructural analysis of MgZn-xHAp biocomposites}

The morphology of the samples was obtained by Scanning Electron Microscopy (SEM) equipped with EnergyDispersive X-Ray Spectroscopy (EDS). MgZn-xHAp biocomposites have a microstructure with irregular shape as shown in Fig. 3. Grain size is getting smaller with increasing HAp composition in the sample. The results of the EDS shown that there is only $\mathrm{Mg}$ element in the grain and there are HAp and $\mathrm{Zn}$ in the grain boundary (Fig. 4).

Hydroxyapatite agglomeration is formed in the microstructure of $\mathrm{MgZn7 \%} \mathrm{HAp} \mathrm{and} \mathrm{MgZn9 \% HAp.} \mathrm{There} \mathrm{are} \mathrm{two} \mathrm{pos-}$ sible causes for the formation of this agglomeration. The first cause is the imperfect milling process and the second one is too much HAp.

\section{Crystallite size}

The crystallite size of the sample calculated using Scherrer equation that has been modified into a straight line equation [18]:

$$
\ln \beta=\ln \frac{K \lambda}{L}+\ln \frac{1}{\cos \theta}
$$

If $\ln \frac{1}{\cos \theta}$ plot to $\ln \beta$ it forms a straight line equation with the cutoff point in $\ln \frac{K \lambda}{L}$. Thus the crystallite size (L) can be calculated by equation:

$$
e^{\ln \frac{K \lambda}{L}}=\frac{K \lambda}{L}
$$

$\mathrm{K}$ is a constant related to the crystalline form with a value of $0.9, \lambda$ is the wavelength of $\mathrm{X}$-rays emitted by $\mathrm{Cu}$ is $1.5418 \AA$, and $\beta$ are the FWHM of the XRD patterns of samples. 


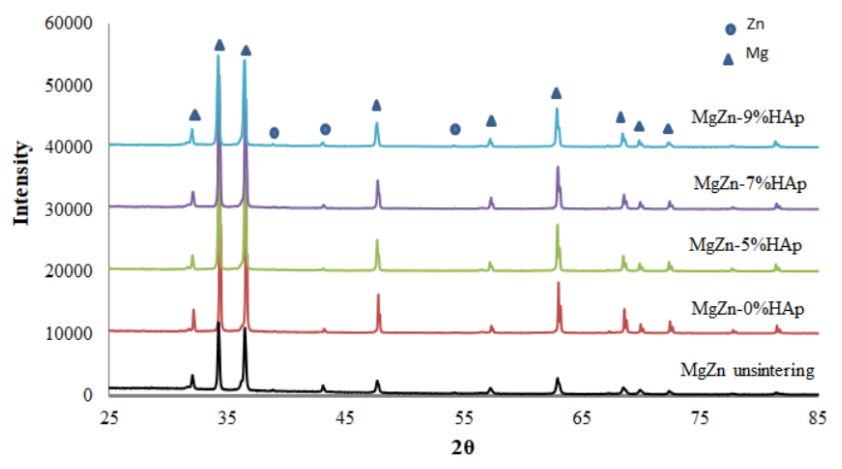

(a) MgZn-xHAp biocomposites

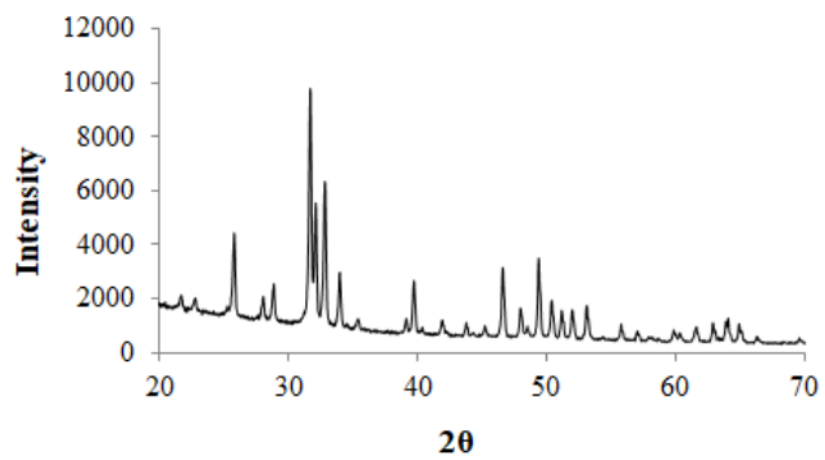

(b) HAp

FIG. 1: XRD pattern.

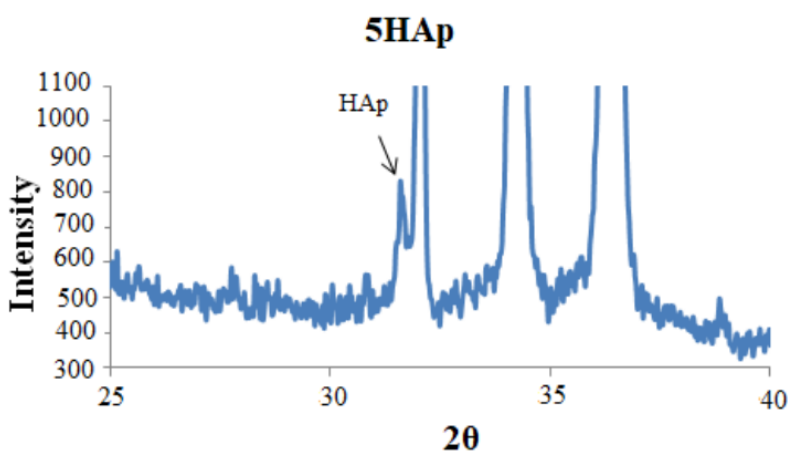

(a) $5 \% \mathrm{HAp}$

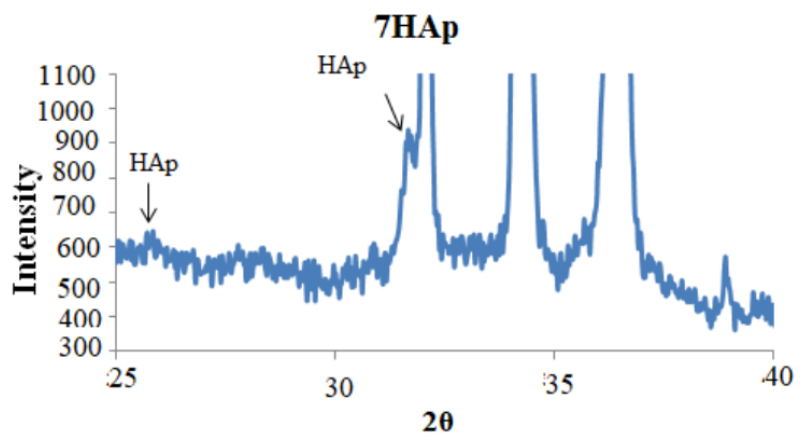

(b) $7 \% \mathrm{HAp}$

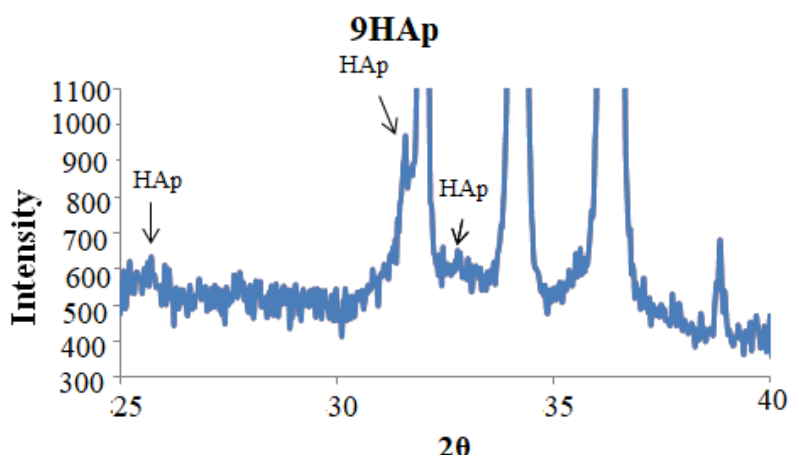

(c) $9 \% \mathrm{HAp}$

FIG. 2: HAp peaks appearing in an XRD pattern of biocomposites MgZn-xHAp, (a) 5\% HAp, (b) 7\% HAp, (c) 9\%HAp.

The calculation results demonstrate that the presence of HAp in the sample affects the biocomposite the crystallite size (Table III). The more amount of HAp in the sample it will produce crystallite size is getting smaller as shown in Fig. 5. These results indicate that HAp can refine crystallite size of MgZn solid solutions. The same thing was also found in the Mg-HAp composite which has been reported in previous studies $[5,8-10]$.

\section{Corrosion rate MgZn-xHAp biocomposites}

Corrosion testing was performed using a potentiostat at room temperature. The sample to was cleaned first by polish- ing then immediately put into the test solution. There are three types of test solutions used, namely $\mathrm{NaCl} 0.9 \%$, Lactate Ringer and Aquadest. The third solution represents the human body fluids. The corrosion rate of materials is calculated by the Faraday Equation [19]:

$$
C R=K \frac{I_{\text {coor }}}{\rho} E W
$$

The electrochemical parameters obtained from the polarization test are shown in Table IV. The corrosion current $\left(\mathrm{I}_{\text {coor }}\right)$ of $\mathrm{NaCl}$ solution has a greater value than in other test solutions. It because the concentration of $\mathrm{NaCl}$ ions is greater 


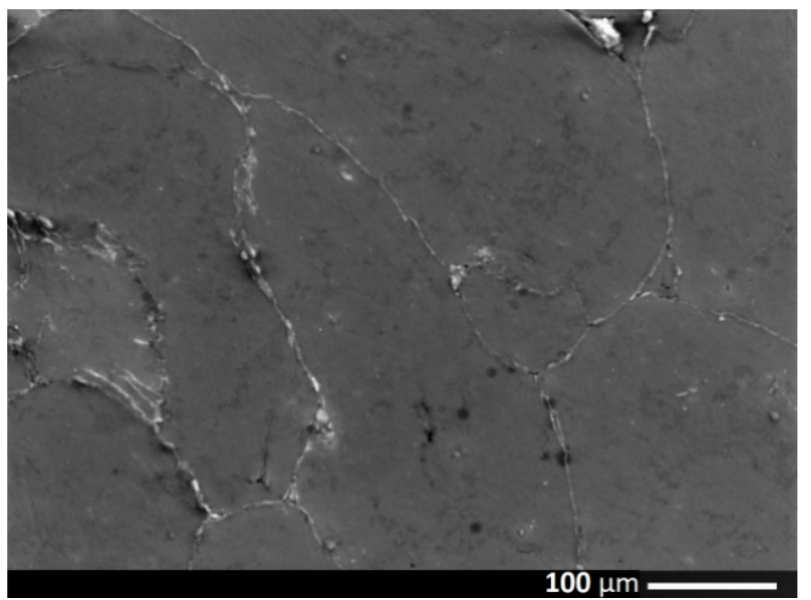

(a) $5 \% \mathrm{HAp}$

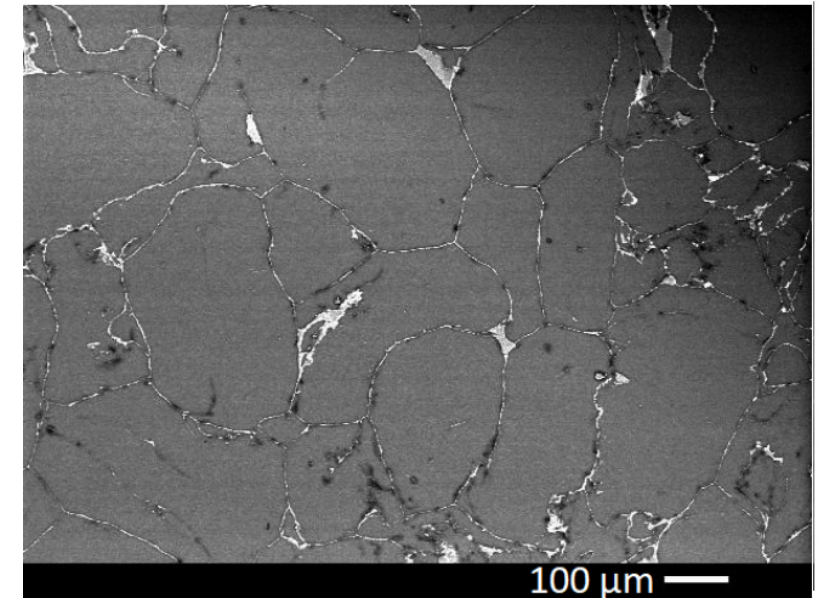

(b) $7 \% \mathrm{HAp}$

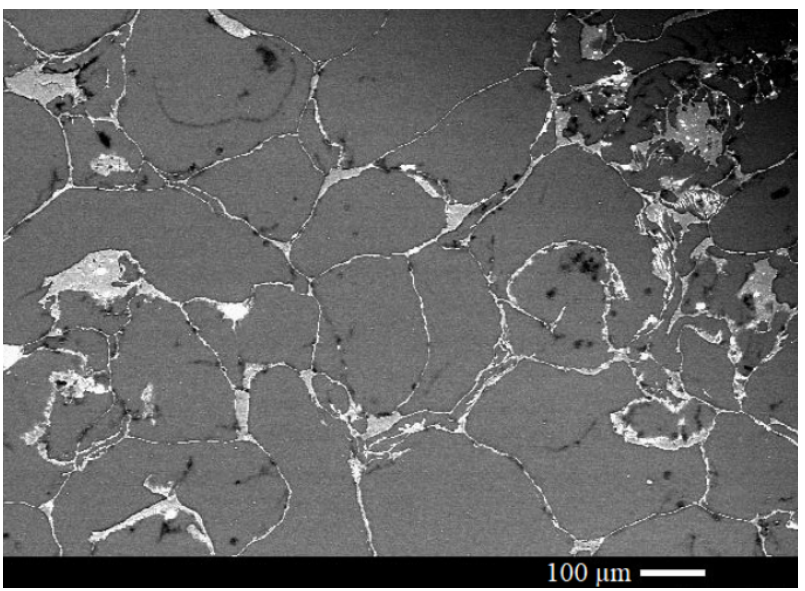

(c) $9 \% \mathrm{HAp}$

FIG. 3: SEM image of MgZn-xHAp biocomposites, (a) 5\% HAp, (b) 7\% HAp, (c) 9\%HAp.

TABLE III: Crystalite size calculation.

\begin{tabular}{ccccc}
\hline \hline Sample & Straight line Equation & Intersection & $\mathrm{k} / \mathrm{L}$ & $\mathrm{L}(\mathrm{nm})$ \\
\hline & & & & \\
MgZn-0\%HAp & $\mathrm{y}=-2.0494 \mathrm{x}-5.879$ & -5.879 & 0.002797581 & 49.01 \\
MgZn-5\%HAp & $\mathrm{y}=-2.0494 \mathrm{x}-5.879$ & -5.7188 & 0.003283649 & 41.75 \\
MgZn-7\%HAp & $\mathrm{y}=-1.8543 \mathrm{x}-5.6228$ & -5.6228 & 0.003614506 & 37.93 \\
MgZn-9\%HAp & $\mathrm{y}=-1.4256 \mathrm{x}-5.4659$ & -5.4659 & 0.004228534 & 32.42 \\
\hline \hline
\end{tabular}

compared to other solutions. Ion in solution will act as a conductor connecting the counter electrode to the working electrode. The solution with higher concentration of ions has the greater conductivity of the current, so that it has a greater corrosion current. The value of $\mathrm{I}_{\text {coor }}$ in Table IV tends to decrease with the increase HAp in the sample and it occurs in all test solutions. This is due to the HAp which occupies the grain boundaries of the microstructure so that it can slow the corrosion process on the material.

Corrosion rate calculation results are presented in Table V. Based on data in Table V, it is obtained that the corrosion resistance of the sample is getting better with increasing HAp composition in the sample. This is seen in all test solutions
TABLE IV: Polarization electrochemical parameters.

\begin{tabular}{ccccccc}
\hline \hline Sample & \multicolumn{2}{c}{$\mathrm{E}_{\text {coor }}(\mathrm{mV})$} & \multicolumn{4}{c}{$\mathrm{I}_{\text {coor }}\left(\mu \mathrm{A} / \mathrm{cm}^{2}\right)$} \\
& Aquadest & $\mathrm{NaCl}$ & $\mathrm{RL}$ & \multicolumn{4}{c}{ Aquadest $\mathrm{NaCl}$} & $\mathrm{RL}$ \\
\hline & & & & & & \\
MgZn & -1452.34 & -1617.5 & -1606.8 & 0.46 & 1.24 & 0.8 \\
MgZn-5HAp & -1494.17 & -1616.9 & -1599.1 & 0.32 & 0.59 & 0.61 \\
MgZn-7HAp & -933.83 & -1059.5 & -1590.2 & 0.15 & 0.36 & 0.25 \\
MgZn-9HAp & -1425.33 & -794.03 & -1593.7 & 0.19 & 0.3 & 0.13 \\
\hline \hline
\end{tabular}

used. The improvement of corrosion resistance is caused by HAp which occupies the grain boundary. HAp is minimiz- 


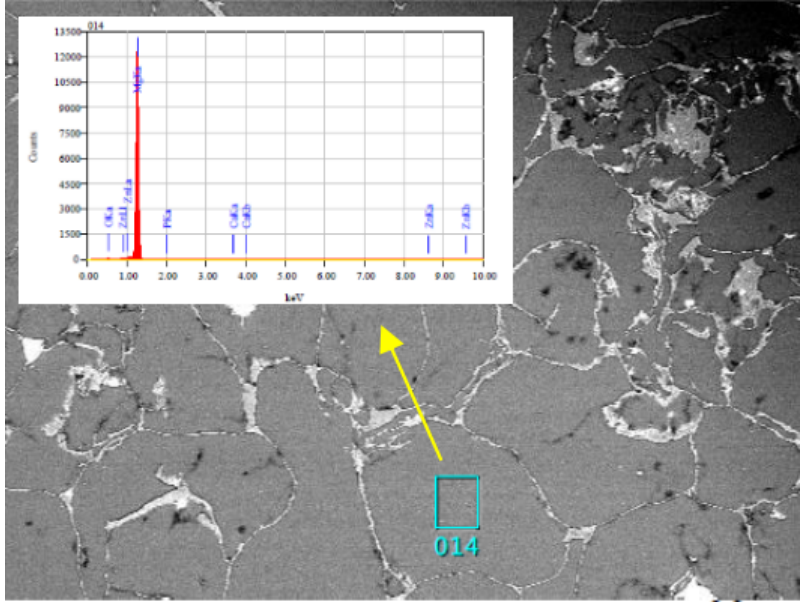

(a)

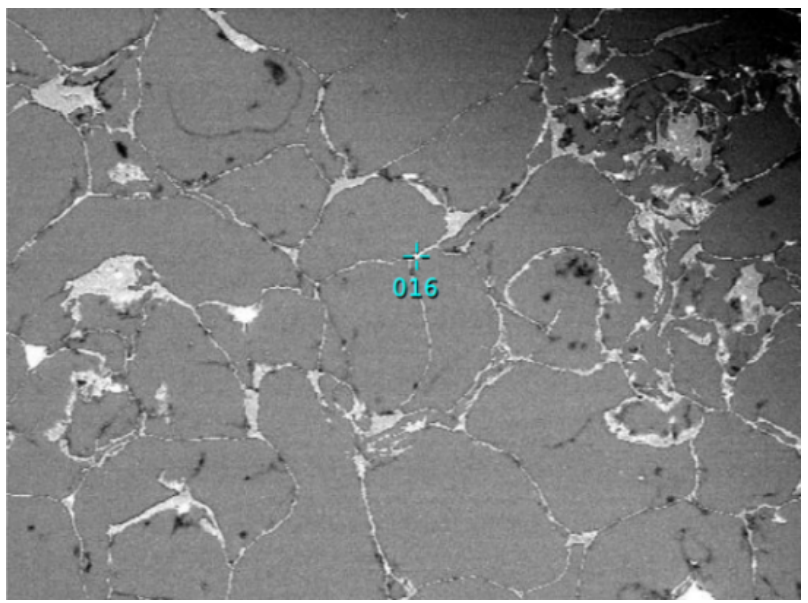

(c)

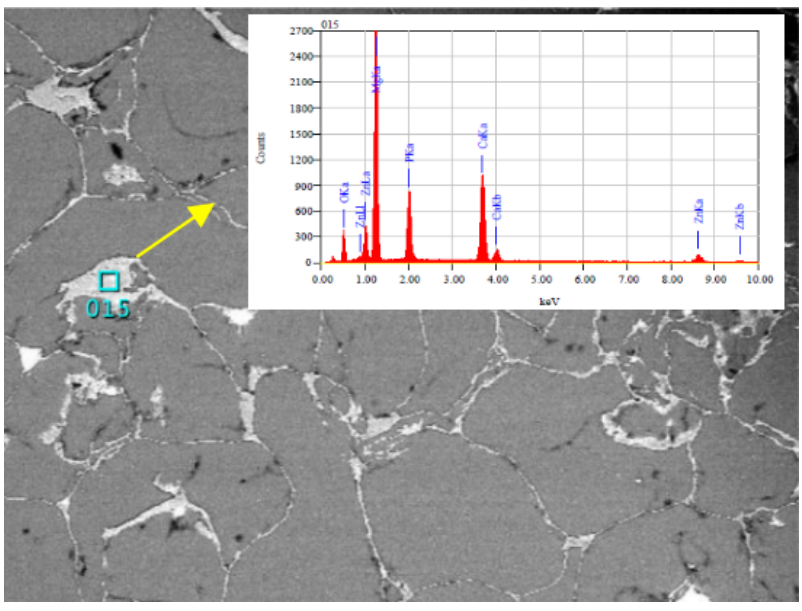

(b)

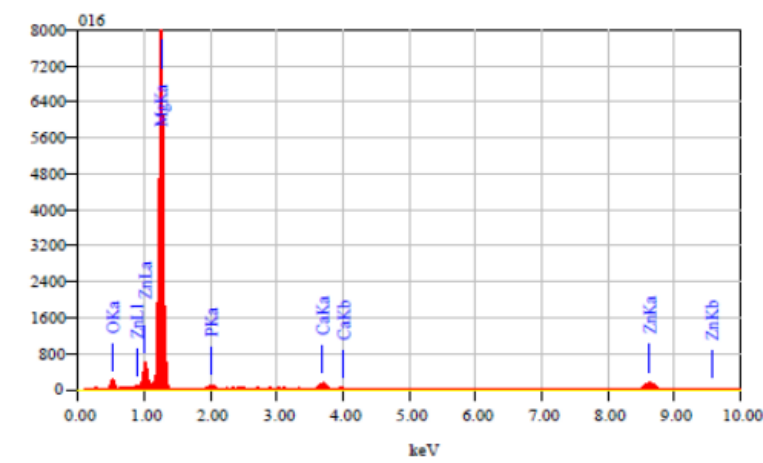

(d)

FIG. 4: EDS of MgZn-9\% HAp Biocomposite.

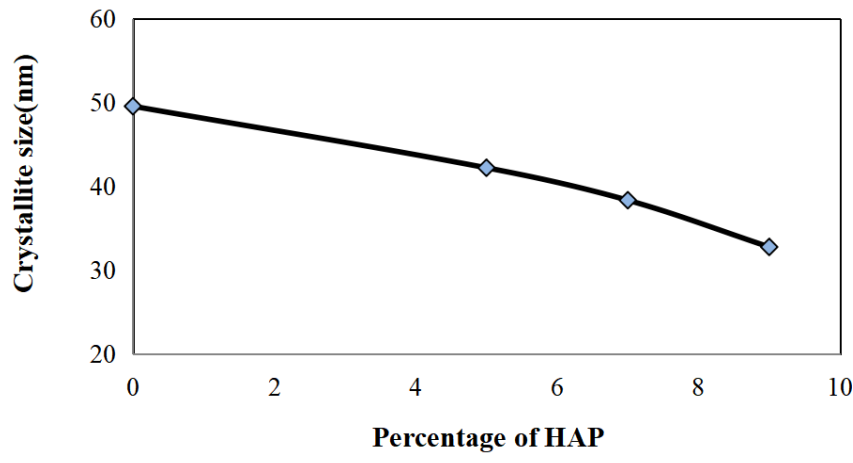

FIG. 5: The effect of HAp on the crystallites size of MgZn-xHAp biocomposites.

ing the surface area of the metal exposed to the solution and reducing the $\mathrm{Mg}$ corrosion current. Nasution and Hermawan said that engineered microstructure and grain size can improve the corrosion resistance of $\mathrm{Mg}$ [4], therefore the smaller crystallite size is also a factor which leads to improve corrosion
TABLE V: Corrosion rate calculation in MgZn-xHAp biocomposites.

\begin{tabular}{cccccc}
\hline \hline Sample & $\left(\rho / \mathrm{cm}^{3}\right)$ & EW & \multicolumn{3}{c}{ Corrosion rate $(\mathrm{mpy})$} \\
& & \multicolumn{5}{c}{ Aquadest } & $\mathrm{NaCl}$ & $\mathrm{RL}$ \\
\hline & & & & & \\
MgZn & 1.8227 & 13.39 & 0.4399 & 1.1847 & 0.7679 \\
MgZn-5HAp & 1.8621 & 13.39 & 0.2978 & 0.5631 & 0.5741 \\
MgZn-7HAp & 1.8783 & 13.39 & 0.144 & 0.3325 & 0.2281 \\
MgZn-9HAp & 1.8949 & 13.39 & 0.174 & 0.279 & 0.1222 \\
\hline \hline
\end{tabular}

rate of the sample.

\section{CONCLUSION}

The biocomposite produced in this study consisted of three phases, namely $\mathrm{Mg}$, $\mathrm{Zn}$ and HAp. Some of the $\mathrm{Zn}$ atoms have dissolved in $\mathrm{Mg}$ and the rest are at grain boundaries. HAp is also at the sample grain boundaries. The composition of 
HAp affects the characteristics of material produced. The increasing composition of HAP in the sample resulted in smaller grain sizes, smaller crystallite sizes, and better corrosion re- sistance. The largest corrosion rate was found in the $\mathrm{NaCl}$ test solution followed by Ringer lactate and the lowest was in aquadest.
[1] V. H. Banyunegoro, Z. Abidin, A. Jihad, Eridawati, and U. Muksin, Probabilistic Seismic Hazard Analysis for Aceh Region Probabilistic Seismic Hazard Analysis for Aceh Region, IOP Conf. Ser. Earth Environ. Sci., vol. 273, 2019.

[2] M. Muzli et al., The 2016 Mw 6.5 Pidie Jaya, Aceh, North Sumatra, earthquake: Reactivation of an unidentified sinistral fault in a region of distributed deformation, Seismol. Res. Lett., 2018.

[3] M. J. Crow and A. J. Barber, Structural map of Sumatra, no. 1990, pp. 01, 2003.

[4] K. Sieh and D. Natawidjaja, Neotectonics of the Sumatran fault, Indonesia, J. Geophys. Res. Solid Earth, vol. 105, no. B12, pp. 2829528326, 2000

[5] Pusat Studi Gempa Nasional, Peta Sumber dan Bahaya Gempa Indonesia Tahun 2017, 1st ed. Bandung: Kementerian Pekerjaan Umum dan Perumahan Rakyat, 2017.

[6] U. Muksin et al., AcehSeis project provides insights into the detailed seismicity distribution and relation to fault structures in Central Aceh, Northern Sumatra, J. Asian Earth Sci., vol. 171, pp. 2027, 2019.
[7] J. R. Curray, Tectonics and history of the Andaman Sea region, J. Asian Earth Sci., vol. 25, no. 1, pp. 187232, 2005.

[8] B. C. Papazachos, E. M. Scordilis, D. G. Panagiotopoulos, C. B. Papazachos, and G. F. Karakaisis, Global Relations Between Seismic Fault Parameters and Moment Magnitude of Earthquakes, Bull. Geol. Soc. Greece, vol. XXXVI, no. April, pp. 14821489, 2004.

[9] M. Shahin, K. Munir, C. Wen, Y.Li, "Magnesium Matrix nanocomposites for Orthopedic Applications: A Review from Mechanical, Corrosion, and Biological Perspectives", Acta Biomaterialia, Vol.96, pp. 1-19, 2019.

[10] E. Lusiani, S. Anwar, and M. F. Nugraha, Penentuan Tingkat Seismisitas Wilayah Propinsi Aceh Dengan Metode Gutenberg Richter (Nilai a Dan Nilai B), J. Meteorol. dan Geofis., vol. 19, no. 2, p. 71, 2019.

[11] J. Wesseloo, Evaluation of the spatial variation of b-value, J. South. African Inst. Min. Metall., vol. 114, no. 10, pp. 823828, 2014. 